\title{
Emotional Intelligence and Quality of Working Life at Federal Institutions of Higher Education in Brazil
}

\author{
Ana Alice Vilas Boas', Estelle M. Morin² \\ ${ }^{1}$ Departamento de Administração e Economia, Universidade Federal de Lavras, Lavras, Brasil \\ ${ }^{2}$ Service de l'Enseignement du Management, HEC-Montreal, Montreal, Canada \\ Email: ana.alice@dae.ufla.br, estelle.morin@hec.ca
}

How to cite this paper: Boas, A.A.V. and Morin, E.M. (2019) Emotional Intelligence and Quality of Working Life at Federal Institutions of Higher Education in Brazil. Open Journal of Social Sciences, 7, 255-274. https://doi.org/10.4236/jss.2019.72020

Received: November 29, 2018

Accepted: February 25, 2019

Published: February 28, 2019

Copyright () 2019 by author(s) and Scientific Research Publishing Inc. This work is licensed under the Creative Commons Attribution International License (CC BY 4.0).

http://creativecommons.org/licenses/by/4.0/ (c) () Open Access

\begin{abstract}
People have prioritized even more the quality of life in the most diverse places of work. Quality of Working Life (QWL) can be analyzed from some indicators and factors that help to evaluate the workplace and the people who work on it. In addition, the personal characteristics also interfere in the QWL perception level. In this context, in this article, the objective is to analyze the emotional intelligence (EI) and Quality of Working Life factors in the professors' work at federal institutions of higher education in Brazil. The data were collected by a questionnaire composed of scales to identify some variables of individual differences and QWL factors. The survey instrument was sent via Survey Monkey to university professors from 16 federal higher education institutions in the Southeast, Midwest, and Federal District. Once downloaded, the data were analyzed using SPSS software version 21. After the analysis, it is realized that EI can be analyzed from five components: well-being, self-control, emotionality, sociability and emotions recognition. It was observed that there are significant correlations between Emotional Intelligence and QWL factors. Furthermore, there are significant relations between the life events, EI and QWL factors.
\end{abstract}

\section{Keywords}

QWL, EI, Professors, Work Organization

\section{Introduction}

Concern about issues related to the labor field has increased in recent years [1]. For this reason, [2] emphasizes that work has a fundamental character at 
people's life in the modern society. It is at work that we spend much of our time.

In the present day, organizations are inserted in a globalized and competitive environment. This causes a greater search for results, leading to a greater demand by the workers, thus they need to withstand loads and pressures constantly. However, organizations note the great need to promote quality of working life policies, aiming to improve the employees' well-being, and their productive capacity.

Nowadays, the Quality of Working Life is an issue that is extremely important, because "it is at work that the individual has the conditions to discover their potential for growth as a human being, to value themselves, to develop their self-esteem and to seek happiness" ([3], p. 2). According to Nadler and Lawler (1983) apud ([4], p. 75), "QWL is the great hope of organizations to reach high productivity levels, without forgetting the motivation and satisfaction of the individual".

According to [5], p. 1, Quality of Working Life (QWL) is related to "mobilization, personal commitment, participation with the employees' well-being in the company task execution, aiming to achieve the Total Quality goals". Quality of Working Life should be a way to improve the working conditions of each individual present in the organization, so that there is a higher level employee satisfaction.

The teaching profession can be treated as different from other work activities due to its complexity and the physical and emotional exhaustion levels that are part of this routine. The formal education process originates from the knowledge that is produced by society and this is due to the demands of survival experiences or individual and/or collective productions of a particular social group [6]. The teaching has several particular characteristics. In this form, it is seen as a professional practice that can generate physical and psychic problems in the individual. The constant use of voice and the need to change the tone several times can cause callosity as already observed in studies investigating vocal cord wear on teachers.

The professors' health is directly linked to social, economic and technological factors and these professionals are conditioned to risks of various natures, among which the physical, mechanical and ergonomic present in their routine work. Considering that professors have a central role in the education of the present society, it is necessary to recognize the casual existence between professor work and the sickness of these professionals. Several changes have been taking place in labor and employment relations, which is indicative of a phenomenon that some authors call "precariousness of current working relations" also present in the teaching work processes [7].

The teaching profession presents a compound of sickness related to the activity that is very characteristic, especially regarding the psychological and behavioral symptoms related to stress and other profession demands. On the other hand, [8] argues that university employees play a vital role in the creation and 
development of knowledge and innovation, as well as education and training for all society. Thus, it is important that government managers from public university find ways to protect their professors and other team members from the rising stress levels due to increasing demands. As an example of this increase demand in the academic field, we can highlight the huge demand for publication in impact journals to support academic careers and maintain post-graduate programs.

On this subject, many studies focus on the role of "Publish or Perish" and this role has increased the academic stress for professors and researchers and has thereby affected the quality of working life. It is because to publish the professors need to work longer hours and devote themselves to their own research and their masters, doctoral and post-doctoral students' research. All these pressures contribute to work-related stress, imbalance between life and work, mental, physical and emotional tension, and can cause different health problems and even about workplace relation.

In the present research has as objective to analyze the emotional intelligence and Quality of Working Life factors of professors from federal institutions of higher education in Brazil. Next, there will be a brief description of the Emotional Intelligence studies and the theoretical basis on the QWL factors. Then, a methodology description used in the field research and the data analysis and the results obtained is presented, as well as a brief discussion of them in relation to previous studies and research on the subject in question. Finally, there are conclusions, suggestions and limitations of this research.

\section{Theoretical Framework}

\subsection{Quality of Working Life: Origins and Models}

Most of human being life is occupied by work, that is, people make most of their time at work, instead of being with their family and friends. From birth, we are already prepared for work and we are given the idea that without work there is no means of survival.

Some people consider that without work it is not possible to live well, while others say that with work it is also possible to live badly. Even though the individuals are not at workplace all the time, their lives revolves around their job most of the time. The pressure for results, for a space in the market, makes the work permanent in the people's life in the present day. With this, organizations increasingly understand the importance of the quality of life of their workers, as it influences their professional career and with this, organizations become worried and offer an environment that provides to the individual safety, comfort and well-being.

The term quality of working life was used by Louis Davis in the 1970s and for this author the concept refers to the concern for the well-being of workers in the performance of their tasks. Whereas, for [9] quality of working life (QWL) refers to the favorable and unfavorable points people's workplace. 
The theme Quality of Working Life is evidenced in the past by the search for worker satisfaction. In the eighteenth and nineteenth centuries, working conditions began to be studied in a scientific way, first by the School of Human Relations [10]. According to this author, the School of Human Relations, concerned was with the psychosocial aspects of work, it was one that presented the greatest identification with the Quality of Working Life movement.

Despite such studies, Quality of Working Life was only evident in the early 1950s in England, when Eric Trist and collaborators studied a macro model to treat the trinomial Individual-Work-Organization. Since then, a sociotechnical approach has emerged from work organization, which is based on the satisfaction of the worker at work and with work.

According to [11], despite the concern with QWL is not recent, the implementation of specific programs has been occurring more recently due mainly to the direct impact of the employees' physical and mental health aspects on the level of productivity and organizational results. Thus, [12] defined the concept of quality of life at work as the general state of well-being in the workplace, and this concept was later used in more recent studies such as [13] [14] [15] [16] and [17].

In this context, [14] highlights the existence of factors that determine QWL as a clear object of research in the field of Psychology, Organizational Studies and Work Psychology. These factors can be understood from the ways of work organization as shown in Figure 1. In the QWL systemic model, there are the following factors: usefulness of the work or work purpose, autonomy and professional development opportunities that result from the characteristics of the work itself, and also lead to the sense of work indicator. In addition to these, there is moral rectitude, relations with coworker and superiors and the recognition that are characteristics result from the interpersonal relations that are processed in the workplace, also lead to the sense of work indicator. The ways of work organization also determine the workload, working hours and safety conditions at work or the perception of insecurity at work. As for the workload, it can be subdivided into physical load, mental load and emotional load [17] and [18]. In addition, Figure 1 shows other variables, considered as indicators or components of QWL, namely: health and psychological well-being, psychological illness and suffering, commitment and work-life balance.

According to [19], these factors can positively affect (in terms of worker's health) or negatively (causing illness and psychological suffering) the quality of working life and lead the individual to have a good work experience or develop defensive strategies to try to improve their QWL. Besides that, individual differences should also be taken into account to analyze the interrelationship of model variables. As an example may mention the case of work-related stress, which is perceived differently by people who perform the same work. Therefore, it should be considered a QWL indicator and not a QWL factor.

Both the QWL factors and the indicators are relevant in the QWL understanding. But, this article deals only with the QWL factors in order to better 


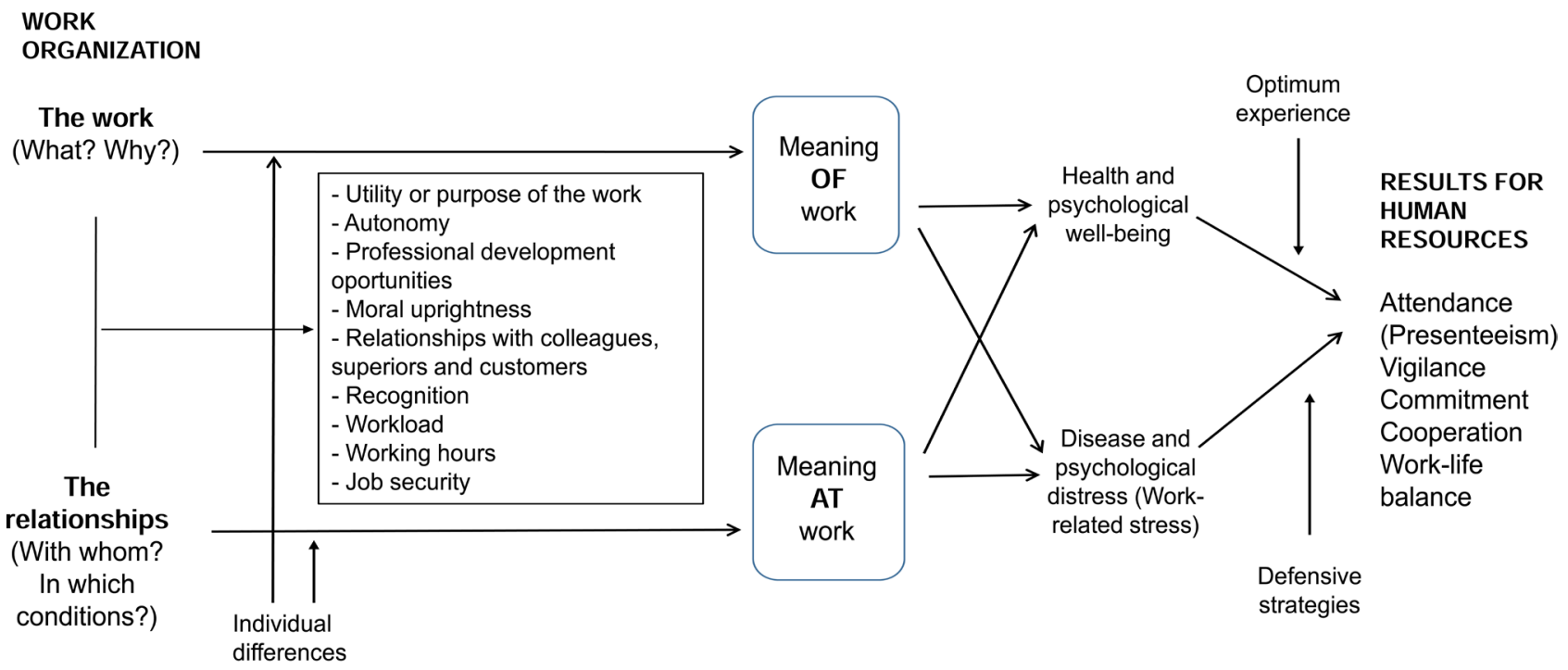

Figure 1. Systemic quality of working life model.

explore the research results. However, the complete research encompassed the study of the factors and indicators in these 10 universities and in 6 other federal universities of Minas Gerais that had their results analyzed and published separately. The results of the QWL indicators for these 10 institutions and for the 6 federal institutions of higher education in Minas Gerais were also published separately [20] [21] [22] and [23]. The theoretical basis for the model, including the variable of Emotional Intelligence and the QWL factors, is briefly presented below.

\subsection{Emotional Intelligence}

In 1920, psychometrician Robert L. Thorndike at Columbia University used the term "social intelligence" to describe the ability to understand and motivate others [24]. In 1983, Howard Gardner, in his theory of multiple intelligences [25], introduced the idea of including both the concepts of intrapersonal intelligence (ability to understand oneself and to appreciate one's feelings, fears and motivations) as well as intelligence interpersonal (ability to understand the intentions, motivations and desires of others). For Gardner, intelligence indicators such as IQ do not fully explain cognitive ability [26]. Thus, although the names given to the concept have varied, there is a common belief that traditional definitions of intelligence do not give a full explanation of their characteristics.

The first use of the term "emotional intelligence" is usually attributed to Wayne Payne, cited in his doctoral thesis, in 1985 [27]. The term, however, had previously appeared in texts by Hanskare Leuner, in 1966 [28]. Stanley Greenspan also presented an emotional intelligence model, in 1989 followed by Peter Salovey and John Mayer in 1990 [29] and Daniel Goleman in 1995 [30].

Emotional intelligence is a concept in psychology that describes the ability to recognize and evaluate one's own feelings and those of others as well as the ability to deal with them. From the philosophy point of view, it is the competence 
responsible for much of the success and leadership ability of a human being. Statements describe attitudes and behaviors in general. There is no right or wrong answer, since the intention to trace the individual's EI profile [31] and [32].

The emotional intelligence concept was proposed by Salovey and Mayer in 1990 to describe this form of human intelligence that involves the ability to recognize the meaning of emotions, their own and others, and take into account to promote the environment adaptation. This proposal reflects two ways of intelligence identified by [25] Gardner in 1983: intrapersonal intelligence and interpersonal intelligence. The first is the ability to discern one's own feelings to better adapt to the events that move us; generates self-management. The second is the ability to understand others, their emotions and feelings, in order to respond appropriately; this promotes good management of your relations.

The emotional quotient was measured using the short version of the Petrides Emotional Intelligence Quotient [33], translated by [32]. That emotional quotient measure has three dimensions: self-awareness, self-control, and optimism. Nevertheless, other studies such as by [34] found other dimensions in the EI structuring.

In addition to Emotional Intelligence, other variables of individual differences can be used to characterize the sample profile and help to draw parallels between the QWL indicators and factors, such as the Striking events that the individual faces during his/her life [19].

\subsection{Quality of Working Life Factors}

As previously reported, [14] and [17] highlighted the factors that determine Quality of Working Life. In this section, we will describe their importance. In the QWL systemic model there are QWL indicators (components), QWL factors (determinants), individual differences variables and confronting strategies that help to delineate QWL [19].

Reference [14] argue that for work to be meaningful for the individual, it is important to do something that is useful for something or someone, or a job that contributes to others or even to society. "People are looking for a job that allows them to feel necessary" and they claim that "the work purpose affects the Quality of Working Life in different ways and degrees" ([16], p. 4). The work organization involves the relations that unfold in the workplace and affect the meaning of the work [19]. The social utility of work or work purpose may positively or negatively affect the quality of working life, since it influences in the perception of the sense of work [35].

Walton (1973) apud [36] affirms that a program of Quality of Working Life when properly proposed, aims to guarantee the confirmation of a more humanized organization, wherein the work simultaneously assumes a high degree of responsibility and autonomy, the individuals receive performance feedback to enrich their jobs and develop their own lives. Autonomy refers to responsibility 
for work. When the individual feel that they have autonomy in their work, one can have the identity and meaning of the work discovered by them, resulting in a possible self-realization in the organization.

"Human self-realization imply finding valid purposes that give meaning to human existence in personal life plans and at work" ([37], p. 342). Richard Walton (1973) apud [37] established some dimensions that allow identifying and evaluating the existence of quality of life in an organization. These dimensions are Opportunity for use and capacity development; Opportunity for continuous growth and security; Social integration at work; Fair and adequate compensation; Work conditions; Constitutionalism; Work and the total space of life; and Social relevance of work life. The set of these development opportunities can help in the healthier environments construction and focus on the individual's well-being because they give more meaning to the work itself. Finally, in order to make the work more sense and meaningful to the worker, it should be pleasurable for the people who execute it [14].

The characteristics of the interpersonal relations that unfold in the workplace determine the sense at work [38]. Therefore, some factors can be listed from the characteristics of these relations, such as moral rectitude. Regard to moral rectitude, [14] point out that this is a very important characteristic, but little appears in the literature on the work organization. It is possible that scandals in a particular business would lead to insights about moral rectitude into social and organizational practices. To make sense in the workplace and for it to be meaningful, it must be executed in an environment that fosters the development of ethical, fair and positive professional relations.

For [39], the nature of personal relations is an important dimension of Quality of Working Life. Therefore, the work should allow the development of relations with coworker and superiors helping each other in the proper accomplishment of the work or facing difficulties in the workplace so that the same can develop good working relations. The relation with coworker and superiors is a work-related characteristic and an important environmental factor for QWL, as it directly influences the harmony and well-being of the corporate environment and the professional themselves. Additionally, relation problems at work, whether, with coworker, bosses, subordinates and even clients greatly affect the quality of personal and family life. In the case of client relations, they are more relevant when it comes to service providers companies wherein professionals have more direct contact with them, such as students in schools or universities [6] and [40].

According to [41], employees make comparisons of their work with that of their coworker by checking experience, effort, education, competence, and results obtained, such as pay, increase and recognition among them. Those who contribute more to the organization expect to receive more in terms of reward, such as status, valuation, bonuses, higher pay, etc. Maslow, apud [36], in his theory emphasizes that the worker has factors that influence his/her satisfaction beyond work, such as personal achievements, recognition in the workplace, 
permanent professional growth, social position, etc. Emphasize that, workplace recognition is a factor that influences the individual satisfaction. According to [42] and [43], recognition and appreciation are essential to encourage productive behavior and the development of individual's self-esteem, which also helps in commitment with work and the organization.

The justice at work is, in a way, related to the feeling of moral rectitude, but this feeling implies in a perception of justice in the processes of decision making, in the equity of the management practices and in the ways of people treatment in the workplace [34] and [44]. Therefore, according to [44], justice is composed of three dimensions: procedural (the procedures that are followed to take decisions), distributive (the equity of reward practices) and interactional (how the manager leads to the employees).

In addition to those already mentioned, another group of factors that is directly related to the ways of work organization refers to the workload [19]. High levels of perceived workload occur when task demands exceed the individual's ability to meet these demands [15]. The study of workload can help work psychologists and ergonomists to distinguish between efficiency of competing projects of the employment of contemporary systems and help managers to provide a better workplace [45]. Workload can be used to provide insights into specific job characteristics and work relations that lead to the meaning of the work [34]. High levels of perceived workload occur when task demands exceed the individual's ability to meet these demands. In this context, some studies have shown that periods of low workload can cause fatigue whether the individual needs to maintain attention on the task for an extended period of time [46]. Consequently, this fatigue state causes deficits in motivation and performance, and health, well-being and safety problems [47].

Reference [48] points out the Quality of Working Life, from the beginning of the movement, which was initiated by Elton Mayo and his collaborators, from the emphasis on human relations and opens space for discussion of issues related to the physical and mental health of the worker. Current studies increasingly show health problems caused by excessive workload [18]. The workload that can affect quality of life is related to the physical, mental and emotional load. In the specific case of university professors, there is a very large charge for publications in qualified and impact journals, which increases the workload. Professors need to devote themselves to a variety of research and administrative practices to manage their research and generate material for publication. In addition to the work of academic orientation at the level of Scientific Initiation, Master's and Doctorate, because currently the focus is "to publish, appear or perish" [49] and [50].

According to [3], QWL can be associated with the worker's feelings about their work, how the physical conditions of the environment can reflect in work safety, and can alter their levels of satisfaction and motivation, which consequently influence productivity. For [51], the feeling of job security is associated with the feeling of job stability and the possibility of fulfilling its established 
commitments. Thus, job insecurity can also be seen as a stressor with numerous negative results for the worker as shown by some international studies [52] and [53]. A recent meta-analysis on job insecurity by [52] shows that job satisfaction and organizational commitment are the two most frequently studied relations and the most ubiquitous reactions to job insecurity.

In summary, these are some aspects to be considered on the theoretical basis that supports the QWL systemic model [19] and serve as basis for discussions of the results of this research.

\section{Methodology}

This article is based on the quantitative research approach. Quantitative research uses statistical and mathematical methods to support its analysis. It has the best treatment for questions as "who", "what" and "where" [54] and it is appropriate to the theory-testing process. However, questions of a more explanatory nature as "how" and "why" cannot be addressed simply by quantitative data, requiring the use of qualitative methods for its analysis.

Regarding the objectives, the present work can be characterized as descriptive and exploratory. The descriptive research aims to define or describe a certain phenomenon, in which the researcher observes, registers, analyzes, classifies and interprets the facts, and aims to establish a relation among variables [55] and [56]. Exploratory research is discovery-oriented and used by researchers when it has little information, as well as the purpose of making explicit a particular research problem ([55] and [57]).

The questionnaire was designed to evaluate Emotional Intelligence, striking events and the university professors' quality of working life. More specifically, it includes scales that measure: Emotional Intelligence (30 affirmations) [33], striking events with 20 situations that may affect an individual's childhood, youth and adult life [58], the work itself focused on work characteristics (11 affirmations) and labor relations (15 affirmations) according to the scale elaborated by [38]. Professors were asked to indicate in what degree they agreed to the demonstrations, using a form ranging from "I strongly agree" to "I strongly disagree". The texts of the statements were revised to suit Brazilian Portuguese. The sense of job security was measured by the [51] scale which contains 7 statements. As an example of these affirmations we can cite: I can stay on this job as long as I want; While I do a good job I am sure that I will keep my job in this organization; and The salary I receive is fair, compared to other people in the same position, in other organizations. Response options ranged from 1 (I strongly disagree) to 6 (I strongly agree).

As for the workload, the objective was to measure the physical load (time to perform tasks), mental load (complex tasks) and emotional load (emotional work related to human relations) based on the studies of [34] and [59]. The workload scale consisted of 15 statements with 6 response options ranging from

"Never-Not once" to "All Time-Every Day". In addition, the professors were 
asked to report the number of hours worked per day and week and other issues related to their professional activity within the university. A pre-test was performed to validate the translation of all scales and understanding of other personal and professional information questions.

The population of this research was composed by professors from 16 Federal Public Institutions of higher level education from the country. The questionnaire was sent via Survey Monkey to 10,769 professors, according to data below.

- 671 professors from the Federal University of Goiás (UFG),

- 505 professors from the University of Brasilia (UnB),

- 1197 professors from the Federal University of São Paulo (UNIFESP),

- 751 professors from the Federal University of Rio de Janeiro (UFRJ),

- 141 professors from the Federal University of Grande Dourados (UFGD),

- 803 professors from the Federal University of São Carlos (UFSCAR),

- 164 professors from the Federal University of Mato Grosso do Sul (UFMS),

- 608 professors from the Federal University of ABC (UFABC),

- 334 professors from the Fluminense Federal University (UFF),

- 373 professors from the Federal Rural University of Rio de Janeiro (UFRRJ).

- 441 professors from the Federal University of Itajubá (UNIFEI),

- 1238 professors from the Federal University of Uberlândia (UFU),

- 418 professors from the Federal University of São João Del Rei (UFSJ),

- 1494 professors from the Federal University of Juiz de Fora (UFJF),

- 1316 professors from the Federal University of Minas Gerais (UFMG), and

- 320 professors from the Federal University of the Triângulo Mineiro (UFTM).

Since universities were not able to provide their professors' e-mail list, their contact was copied through the institutional websites by three Scientific Initiation Fellowships students, but the institutions usually only provide contacts of professors involved in post-graduation or in some sectors. Therefore, the total number of professors does not correspond to the reality of the respective institutions, since they have much more professors than those registered in Survey Monkey. The invitations were sent from October 2016 to early May 2017 when the data was downloaded for the first analysis. An average, five reminders were sent to all professors from all institutions, since the rate of return for this type of research is usually very low. It is worth mentioning that the research project and the data collection instrument were submitted to the UFLA Human Research Ethics Committee, code CAAE 49850715.3.0000.5148, and was approved in December 2015.

The total of questionnaires answered by the professors of these 16 institutions reached 1038, but some were discarded because they contained many unanswered questions. For that reason, some variables present more response rate than others. The data below show the number of questionnaires answered per institution.

- 69 professors from the Federal University of Goiás (UFG),

- 45 professors from the University of Brasilia (UnB), 
- 121 professors from the Federal University of São Paulo (UNIFESP),

- 32 professors from the Federal University of Rio de Janeiro (UFRJ),

- 24 professors from the Federal University of Grande Dourados (UFGD),

- 91 professors from the Federal University of São Carlos (UFSCAR),

- 12 professors from the Federal University of Mato Grosso do Sul (UFMS),

- 35 professors from the Federal University of ABC (UFABC),

- 36 professors from Universidade Federal Fluminense (UFF),

- 31 professors from the Federal Rural University of Rio de Janeiro (UFRRJ).

- 46 professors from the Federal University of Itajubá (UNIFEI),

- 75 professors from the Federal University of Uberlândia (UFU),

- 59 professors from the Federal University of São João Del Rei (UFSJ),

- 140 professors from the Federal University of Juiz de Fora (UFJF),

- 77 professors from the Federal University of Minas Gerais (UFMG), and

- 26 professors from the Federal University of the Triângulo Mineiro (UFTM).

For each questionnaire scale, the main components analysis or the main axis analysis were performed, with orthogonal factor rotation in order to reduce the variables observed for a minimum number of dimensions (or components) that describe the maximum proportion of variation for each of the variables, that is, QWL factors. The factorial structure scales, then tested with an analysis of the main axes with orthogonal rotation for some of the factors, once a clear factorial structure was found, the internal consistency of each factor was analyzed in order to evaluate its reliability using the Cronbach alpha. This statistical analysis can perfectly determine the percentage of error variance in the factor measurement, the ideal level being higher than 0.70 , but the acceptable level can be at least 0.60 , according to [57]. From these statistical analyzes, variables and/or factors were finally constructed and ready to be used.

Pearson's correlation analysis was performed to determine the behavior of the variables in question, that is, QWL factors. It is worth mentioning that one could compare the factors per institution, but due to the low return, which generated small samples per institution, this analysis was not implemented.

\section{Results and Discussion}

Table 1 presents the Pearson's correlation coefficients, number of items for each factor and the internal consistency index determined by Cronbach's alpha. The results of this research clearly showed that these professors perceive the differences among the variables of individual differences, as observed by [13] [16] [34] [38] and [60] in other contexts surveyed.

Among the 30 affirmations of the scale, 50\% were recorded to fit the proposed analysis parameter. The results presented in Table 1 show that the correlation coefficients are significant and in the expected direction, demonstrating the information consistency that these measures present for the components of Emotional Intelligence. The chosen variables provide reliable information for Well-being (0.876) and Emotionality (0.730), because the internal consistency 
Table 1. Variables of professors' individual differences from 16 federal institutions of higher education in Brazil.

\begin{tabular}{|c|c|c|c|c|c|c|c|c|c|c|}
\hline & Averages & $\begin{array}{l}\text { Standard } \\
\text { deviation }\end{array}$ & & Well-being & Emotionality & Self-control & Sociability & $\begin{array}{l}\text { Emotional } \\
\text { Recognition }\end{array}$ & $\begin{array}{l}\text { Emotional } \\
\text { Intelligence }\end{array}$ & $\begin{array}{c}\text { Life } \\
\text { Events }\end{array}$ \\
\hline \multirow{3}{*}{ Well-being } & & & Alpha & $(0.876)$ & & & & & & \\
\hline & 55.4343 & 9.34529 & Number of items & 10 & & & & & & \\
\hline & & & $\mathrm{N}$ & 951 & & & & & & \\
\hline \multirow{3}{*}{ Emotionality } & & & r-Pearson's Cor. & $0.520^{* *}$ & $(0.730)$ & & & & & \\
\hline & 52.0009 & 8.30855 & Sig. (2-tailed) & 0.000 & 7 & & & & & \\
\hline & & & $\mathrm{N}$ & 951 & 951 & & & & & \\
\hline \multirow{3}{*}{ Self-control } & & & r-Pearson's Cor. & $0.496^{* *}$ & $0.368^{* *}$ & $(0.670)$ & & & & \\
\hline & 48.5131 & 9.94752 & Sig. (2-tailed) & 0.000 & 0.000 & 6 & & & & \\
\hline & & & $\mathrm{N}$ & 951 & 951 & 951 & & & & \\
\hline \multirow{3}{*}{ Sociability } & & & r-Pearson's Cor. & $0.467^{* *}$ & $0.379 * *$ & $0.397^{* *}$ & $(0.546)$ & & & \\
\hline & 47.5342 & 9.56378 & Sig. (2-tailed) & 0.000 & 0.000 & 0.000 & 4 & & & \\
\hline & & & $\mathrm{N}$ & 951 & 951 & 951 & 951 & & & \\
\hline \multirow{3}{*}{$\begin{array}{l}\text { Emotional } \\
\text { Recognition }\end{array}$} & & & r-Pearson's Cor. & $0.467^{* *}$ & $0.379 * *$ & $0.397^{* *}$ & $10.000^{* *}$ & $(0.603)$ & & \\
\hline & 47.5342 & 9.56378 & Sig. (2-tailed) & 0.000 & 0.000 & 0.000 & 0.000 & 3 & & \\
\hline & & & $\mathrm{N}$ & 951 & 951 & 951 & 951 & 951 & & \\
\hline \multirow{3}{*}{$\begin{array}{l}\text { Emotional } \\
\text { Intelligence }\end{array}$} & & & r-Pearson's Cor. & $0.765^{\star *}$ & $0.670^{* *}$ & $0.702^{* *}$ & $0.850^{* *}$ & $0.850^{* *}$ & $(0.879)$ & \\
\hline & 50.2033 & 7.19289 & Sig. (2-tailed) & 0.000 & 0.000 & 0.000 & 0.000 & 0.000 & 30 & \\
\hline & & & $\mathrm{N}$ & 951 & 951 & 951 & 951 & 951 & 951 & \\
\hline \multirow{3}{*}{ Life Events } & & & r-Pearson's Cor. & -0.061 & -0.037 & -0.011 & 0.015 & 0.015 & -0.019 & - \\
\hline & 2.2441 & 1.69304 & Sig. (2-tailed) & 0.061 & 0.261 & 0.736 & 0.639 & 0.639 & 0.556 & - \\
\hline & & & $\mathrm{N}$ & 934 & 934 & 934 & 934 & 934 & 934 & 934 \\
\hline
\end{tabular}

**. Correlation is significant at the 0.01 level (2-tailed). Source: Research Data.

indexes are greater than (0.70). The components of Self-control (with Alpha 0.670) and Emotional Recognition (with Alpha .603) can still be considered as consist, since according to [14] the values from 0.600 and 0.700 are also valid. However, the Sociability component (with Alpha 0.546) cannot be considered reliable because it was below the acceptable minimum for a significant Alpha that is 0.600 . However, considering the variable Emotional Intelligence in the whole, it has Alpha 0.879. The information are consistent (because the Pearson's coefficients are significant and in the expected direction). The results for each of these variables are briefly described below.

There is a moderate-positive-correlation between emotionality and well-being $(0.520, p<0.000)$. Indicating that the ease with a person gets emotional increases the level of well-being. There is a weak-positive - correlation among emotion recognition and emotionality and self-control $(0.379, \mathrm{p}<0.000)$. In addition, there is a moderate - positive - correlation between emotion recognition and well-being $(0.467, \mathrm{p}<0.000)$. Additionally, there is a perfect correlation - posi- 
tive - between emotion recognition and sociability $(1.000, \mathrm{p}<0.000)$. Clearly indicating, they are different factors that can determine the relations among other components of Emotional Intelligence.

Considering the variable Emotional Intelligence in the whole, we may say that there are strong positive correlations among almost all components, namely: well-being (0.765), self-control (0.702), sociability (0.850) and emotional recognitions (0.850). In the case of the emotionality component, the coefficient was 0.670 , that is, moderate correlation. All at the significance level of 0.01 indicating the increase of one component leads to the increase of the other and vice versa.

With regard to the Life Events variable, it was measured considering important events of childhood, such as death of father or mother; of adolescence (12 to 18 years), such as separation of parents or living in foster home; and in adult life, such as the death of a child or a loved one, employment dismissal, split up or divorce, or serious problems in court. It was obtained an average 2.2441 striking events for each research participant considering the 3 phases of life, with a standard deviation of 1.69304. Pearson's correlation to Life Events was very weak negative - for well-being $(-0.061)$, emotionality $(-0.037)$, self-control $(-0.011)$, and emotional intelligence as the only variable $(-0.19)$. Nevertheless, it was positive for sociability (0.015) and emotion recognition (0.015). This demonstrates that the effects of striking events on Emotional Intelligence are low, but it can still be considered an important variable for analyzing Quality of Working Life.

Table 2 presents the averages, standard deviations, Pearson's correlation coefficients, number of items for each factor and the internal consistency index determined by Cronbach's alpha. As demonstrate the results presented in this table, the correlation coefficients are significant and in the expected direction, showing the consistency of the information that these measures present. The results of this research clearly showed that these professors perceive the differences between the Emotional Intelligence variable and the factors of Quality of Working Life, as observed by [14] in other performed studies.

The chosen QWL factors provide reliable information (because the internal consistency indexes are greater than 0.70) and consistent information (because the Pearson's coefficients are significant and in the expected direction). The results for each of these factors are briefly described. It can be observed in Table 2 that there is a moderate - positive - correlation between the autonomy at work and the work purpose $\left(0.490^{* *}, \mathrm{p}<0.000\right)$. The size of the Pearson's correlation coefficient means that the two indicators evaluate different QWL aspects. When the autonomy level increases the perception of work purpose also increases.

Likewise, there is a strong - positive - correlation between professional development opportunities and the work purpose $\left(0.637^{\star *}, \mathrm{p}<0.000\right)$, but the Pearson's coefficient size is not high enough to identify one with another factor. In the same way, there is a strong - positive - correlation between professional development and autonomy $\left(0.654^{* *}, \mathrm{p}<0.000\right)$. These relations indicate that they are different factors that can determine the relations among the work characteristics, because the individual feels that having autonomy will be more chance to 
Table 2. Averages, standard deviation, Pearson's correlation among QWL factors, internal consistency indexes and number of items of professors' perception from 16 federal higher education institutions in Brazil.

\begin{tabular}{|c|c|c|c|c|c|c|c|c|c|c|c|c|}
\hline Factors & Averages & SD & & $\begin{array}{l}\text { Work } \\
\text { purp }\end{array}$ & Aut & ProfDev & $\begin{array}{l}\text { Moral } \\
\text { Rect }\end{array}$ & $\begin{array}{l}\text { Hum } \\
\text { relat }\end{array}$ & $\operatorname{Recog}$ & $\begin{array}{l}\text { Work } \\
\text { safety }\end{array}$ & Workload & E I \\
\hline \multirow[t]{2}{*}{$\begin{array}{l}\text { Work purpose } \\
\qquad \mathrm{N}=984\end{array}$} & 53.57 & 6.20 & Alpha & $(0.856)$ & & & & & & & & \\
\hline & & & $\begin{array}{c}\text { Number of } \\
\text { items }\end{array}$ & 4 & & & & & & & & \\
\hline \multirow[t]{2}{*}{$\begin{array}{c}\text { Autonomy } \\
\mathrm{N}=984\end{array}$} & 49.65 & 7.43 & $\mathrm{R}$ & $0.490^{* *}$ & $(0.785)$ & & & & & & & \\
\hline & & & Sig. $(2-t)$ & 0.000 & 4 & & & & & & & \\
\hline \multirow[t]{2}{*}{$\begin{array}{l}\text { Prof. develop } \\
\qquad N=983\end{array}$} & 50.43 & 7.72 & $\mathrm{R}$ & $0.637^{* *}$ & $0.654^{* *}$ & $(0.850)$ & & & & & & \\
\hline & & & Sig. (2-t) & 0.000 & 0.000 & 5 & & & & & & \\
\hline \multirow[t]{2}{*}{$\begin{array}{l}\text { Moral Rectitude } \\
\qquad \mathrm{N}=984\end{array}$} & 44.99 & 10.43 & $\mathrm{R}$ & $0.399^{\star *}$ & $0.480^{* *}$ & $0.522^{* *}$ & $(0.913)$ & & & & & \\
\hline & & & Sig. $(2-t)$ & 0.000 & 0.000 & 0.000 & 4 & & & & & \\
\hline \multirow[t]{2}{*}{$\begin{array}{l}\text { Hum relat } \\
\mathrm{N}=984\end{array}$} & 44.99 & 9.44 & $\mathrm{r}$ & $0.456^{* *}$ & $0.530^{* *}$ & $0.567^{\star *}$ & $0.583^{* *}$ & $(0.873)$ & & & & \\
\hline & & & Sig. (2-t) & 0.000 & 0.000 & 0.000 & 0.000 & 4 & & & & \\
\hline \multirow[t]{2}{*}{$\begin{array}{l}\text { Recognition } \\
\quad \mathrm{N}=984\end{array}$} & 43.14 & 11.33 & $\mathrm{r}$ & $0.454^{* *}$ & $0.560^{* *}$ & $0.618^{* *}$ & $0.729^{* *}$ & $0.729^{* *}$ & $(0.906)$ & & & \\
\hline & & & Sig. $(2-t)$ & 0.000 & 0.000 & 0.000 & 0.000 & 0.000 & 3 & & & \\
\hline \multirow[t]{2}{*}{$\begin{array}{c}\text { Justice } \\
\mathrm{N}=984\end{array}$} & 38.20 & 13.15 & $\mathrm{r}$ & $0.209^{\star *}$ & $0.457^{* *}$ & $0.430^{* *}$ & $0.352^{\star *}$ & $0.343^{\star *}$ & $0.414^{\star *}$ & $(0.802)$ & & \\
\hline & & & Sig. $(2-t)$ & 0.000 & 0.000 & 0.000 & 0.000 & 0.000 & 0.000 & 2 & & \\
\hline \multirow[t]{2}{*}{$\begin{array}{l}\text { Work safety } \\
\qquad \mathrm{N}=973\end{array}$} & 40.81 & 9.07 & $\mathrm{r}$ & $0.168^{* *}$ & $0.438^{* *}$ & $0.355^{\star *}$ & $0.285^{\star *}$ & $0.243^{\star *}$ & $0.325^{\star *}$ & $0.661^{* *}$ & $(0.663)$ & \\
\hline & & & Sig. $(2-t)$ & 0.000 & 0.000 & 0.000 & 0.000 & 0.000 & 0.000 & 0.000 & 7 & \\
\hline \multirow[t]{2}{*}{$\begin{array}{l}\text { Workload } \\
\mathrm{N}=984\end{array}$} & 54.84 & 7.77 & $\mathrm{r}$ & 0.013 & $\begin{array}{c}-0.113^{*} \\
*\end{array}$ & $-0.094^{\star *}$ & $-0.174^{* *}$ & $\begin{array}{c}-0.117^{\star} \\
*\end{array}$ & $-0.173^{\star *}$ & -0.023 & $(0.835)$ & \\
\hline & & & Sig. $(2-t)$ & 0.678 & 0.000 & 0.004 & 0.000 & 0.000 & 0.000 & 0.465 & 13 & \\
\hline EI & 50.20 & 7.19 & $\mathrm{r}$ & $0.353^{* *}$ & $0.349^{* *}$ & $0.254^{* *}$ & $0.358^{* *}$ & $0.345^{\star *}$ & $0.138^{* *}$ & $0.323^{* *}$ & $0.139 * *$ & $(0.879)$ \\
\hline $\mathrm{N}=951$ & & & Sig. (2-t) & 0.000 & 0.000 & 0.000 & 0.000 & 0.000 & 0.000 & 0.001 & 0.000 & 30 \\
\hline
\end{tabular}

Legend: SD (Standard Deviation), Work Purpose (Work Purp), Autonomy (Aut.), Professional Development (Prof. develop), Human Relations (Hum relat), Moral rectitude (Moral Rect), Recognition (Recog), Work safety, Workload, Emotional Intelligence (IE).

develop professionally.

There is a strong - positive - correlation among relations with coworker and moral rectitude $\left(0.668^{* *}, \mathrm{p}<0.000\right)$, but not high enough to confuse both factors. Besides that, there is a strong - positive - correlation between Recognition and Relations with coworker $\left(0.729^{* *}, \mathrm{p}<0.000\right)$ and Recognition and Moral rectitude $(0.729, \mathrm{p}<0.000)$, indicating that they are different factors that can determine relations among the labor relations themselves. 
In this research, the so-called factor of justice proved to be relevant among the characteristics of labor relations, emphasizing the reduction of factors. What did not happen in the Brazil-Canada survey [61]. It should be noted that in the research the Moorman Scale of Organizational Justice [38] was not used, but other issues that are part of the Morin and Dassa scale [38] that deals with the characteristics of the work. The average response for the components of this variable was 38.20 and the standard deviation was 13.148.

There are still moderate - positive - correlations between job security with autonomy and development opportunities (respectively $0.438^{\star *}, 0.355^{\star *} \mathrm{p}<0.000$ ). There are still significant - negative - correlations, but weak between workload and autonomy $\left(-0.113^{* *}\right)$, opportunities for development $\left(-0.094^{* *}\right)$, moral rectitude $\left(-0.174^{\star \star}\right)$, relation with coworker $\left(-0.117^{\star *}\right)$ and recognition $\left(-0.173^{\star *}\right)$ indicating that an increase in workload negatively affects all these QWL factors.

With regard to Emotional Intelligence, it is observed that there are significant - positive - relations with regard to all QWL factors. That is, an increase in the emotional intelligence level improves QWL perception level, for example in $0.353^{* *}$ for work purposes, $0.358^{\star *}$ for moral rectitude, $0.349^{* *}$ for autonomy and $0.345^{* *}$ for relations with coworker.

\section{Conclusions}

In the present day, the quality of working life is strong evidence for the differentiation of one company and another as well as the predominant climate in the workplace. That is why, QWL is a subject that has been studied since 1972 and currently has gained strength in research in the areas of Psychology, Organizational Studies and Work Psychology. As organizations move forward in time, they have been led to offer their employees a work environment that gives individuals better physical and psychological conditions of work and therefore a better quality of life. That brings, in contrast, more commitment of the worker with the job itself and with the organization as a whole and more productivity for the organizations.

In parallel, as the public service offers a high degree of stability, they also feel they have job security. However, with the high responsibility and overload of work, the data demonstrated that an increase in the workload decreases the levels of work purpose, autonomy, development opportunities, moral rectitude, relation with coworker and superiors, recognition and safety at work. The requirements of student orientation, research and publication and conducting administrative activities may be limiting factors of the effects results of workloads on the professor.

Pearson's correlation analysis also showed that the behavior of the QWL factors is consistent with the theoretical basis that supports this research. In addition, it is worth remembering that other articles present the other results of this research. That is the QWL indicators analysis and the role of control variables and socio-demographic and professional characterization variables in a better 
understanding of the model chosen for this study and by QWL in federal educational institutions in Brazil. Emotional Intelligence has been shown to be sub-divided into 5 components, namely: Well-being, Emotionality, Self-control, Sociability and Emotions recognition. It was observed that an increase in the EI level generates an improvement in the perception of all the QWL factors.

Since the research is limited to a quantitative study, the findings could not be deepened analyzed according to the different research realities. Therefore, a precise and detailed description, through documentary analysis, of the educational system contemplating access criteria, academic demands of university professors, working hours, degree of effort, etc. would enrich the findings presented here. On the other hand, in-depth interviews or a focus group could be used to elicit more subjective and personal information that can elucidate personal and professional aspects that affect the teaching performance and their relation with the educational institution and their own personal life. These aspects are directly related to the construct sense of work and the factors of quality of working life.

Due to the limitations of this research, it is also suggested to make comparative analyses among the universities, because as the samples by institutions were small, it was not possible to implement these analyses in this article. With the aforementioned sample of the 16 institutions, comparative analyses and differences of averages could be made for professors who work only in the undergraduate and those who work in the post-graduate course. It is also suggested qualitative research be carried out to better understand the role of EI and the Striking events in the quality of life in public or private universities.

The Federal Public Administration through the Ministry of Education and Culture and other federal and state agencies can use knowledge about EI behavior and QWL factors to evaluate the quality of life of their servers, in order to provide better teaching to the population and contribute to the professors' physical and mental health. Therefore, it is hoped that this work will contribute to the advancement of this subject next to Organizational Studies and University Management.

\section{Acknowledgements}

We would like to thank you the Conselho Nacional de Desenvolvimento Científico e Tecnológico-CNPq for sponsoring this research.

\section{Conflicts of Interest}

The authors declare no conflicts of interest regarding the publication of this paper.

\section{References}

[1] Macêdo, K.B. (2010) O trabalho de quem faz arte e diverte os outros. Editora da Pontifícia Universidade Católica de Goiás, Goiânia.

[2] Menezes, L.M., Nepomuceno, L.H. and dos Santos, A.C.B. (2011) Os Sentidos do Trabalho para um Grupo de Professores de uma Universidade Pública: A Dialética 
Prazer-Sofrimento em Tempos de Flexibilidade. Anais XXXV En ANPAD. Rio de Janeiro.

[3] Pizzolato, B.P., Moura, G.L. and Silva, A.H. (2013) Qualidade de Vida no Trabalho: uma discussão sobre os modelos Teóricos. Contribuciones a la Economía. Abr.

[4] Rodrigues, M.V.C. (1995) Qualidade de vida no trabalho:evolução e análise no nível gerencial. 2 Ed., Vozes Petrópolis, RJ.

[5] Freitas, A.L.P. and de Souza, R.G.B. (2009) Um modelo para avaliação da Qualidade de Vida no Trabalho em universidades públicas. Revista Eletrônica Sistemas \& Gestão, 4, 136-154. http://www.uff.br/sfg/index.php/sg/article/view/82

[6] de Paula, A.V. (2015) Qualidade de vida no trabalho de professores de instituições federais de ensino superior: um estudo em duas universidades brasileiras. Universidade Federal de Lavras, Tese de Doutorado, PPGA, Lavras.

[7] Druck, G. (2011) Trabalho, precarização e resistências: novos e velhos desafios? Caderno CRH, 24, 37-57.

[8] Gillespie, N.A., Walsh, M., Winefields, A.H., Dua, J. and Stough, C. (2001) Occupational Stress in Universities: Staff Perceptions of the Causes, Consequences and Moderators of Stress. Work \& Stress, 15, 53-72. https://doi.org/10.1080/02678370117944

[9] Davis, K. and Newstrom, J.W. (1992) Comportamento Humano no Trabalho. Vol. 1, São Paulo, Pioneira.

[10] Sampaio, J.R. (1999) Qualidade de Vida, Saúde Mental e Psicologia Social: estudos contemporâneos II.

[11] Amorim, T.N.G.F. (2010) Qualidade de vida no trabalho: preocupação também para servidores públicos? Revista Eletrônica de Ciência Administrativa-RECADM, 9, 35-48.

[12] Ketchum, L.D. and Trist, E. (1992) All Teams Are Not Created Equal: How Employee Empowerment Really Works. Sage, Newbury Park, 328 p.

[13] Vilas Boas, A.A. and Morin, E.M. (2016) Indicadores de qualidade de vida no trabalho para professores de instituições públicas de ensino superior: uma comparação entre Brasil e Canadá. Revista Contextus, 14, 1-29. https://doi.org/10.19094/contextus.v14i2.830

[14] Vilas Boas, A.A. and Morin, E.M. (2016) Sentido do trabalho e fatores de qualidade de vida no trabalho: A percepção de professores brasileiros e canadenses. Revista Alcance, 23, 272-292. https://doi.org/10.14210/alcance.v23n3(Jul-Set).p272-292

[15] Vilas Boas, A.A. and Morin, E.M. (2015) Stress no Trabalho, Bem-Estar Psicológico e Comprometimento com o Trabalho: Efeitos e Relações com a Qualidade de Vida no Trabalho. In: Rossi, A.M., Meurs, J.A. and Perrewé, P.L. (Orgs.), Stress e qualidade de vida no trabalho: Stress Interpessoal e Ocupacional, Atlas, São Paulo, 119-140.

[16] Vilas Boas, A.A. and Morin, E.M. (2014) Sentido do Trabalho e Fatores de Qualidade de Vida no Trabalho para Professores de Universidades Públicas do Brasil e do Canadá. XXXVIII Encontro Nacional da ANPAD, Rio de Janeiro, 16 p.

[17] Vilas Boas, A.A. and Morin, E.M. (2014) Fatores de qualidade de vida no trabalho em universidades públicas: uma comparação entre Brasil e Canadá. Congresso de stress da internacional stress management association, 14th Fórum de qualidade de vida no trabalho, Porto Alegre, 1563-1584.

[18] Kinman, G. and Jones, F.A. (2008) Life beyond Work? Job Demands, Work-Life Balance, and Wellbeing in UK Academics. Journal of Human Behavior in the Social Environment, 17, 41-60.

[19] Vilas Boas, A.A. and Morin, E.M. (2014) Fatores de qualidade de vida no trabalho em universidades públicas: uma comparação entre Brasil e Canadá. Congresso de stress da internacional stress management association, 14th Fórum de qualidade de vida no trabalho, Porto Alegre, 1563-1584. 
[20] Pires, A.A.S., Vilas Boas, A.A., Morin, E.M., Taveira, A.M. and Faria, D.A. (2017) Indicadores de Qualidade de Vida no Trabalho de Docentes de Instituições Federais de Ensino Superior das regiões Sudeste, Centro Oeste e Distrito Federal. International Conference on Stress Management, Porto Alegre, Vol. 1, 1-25.

[21] Pires, A.A.S., Vilas Boas, A.A., Faria, D.A. and Morin, E.M. (2017) Indicadores de Qualidade de Vida no Trabalho de Docentes de Instituições Federais de Ensino Superior do Estado de Minas Gerais. X Congresso de Administração, Sociedade e Inovação, Petrópolis, Vol. 1, 1-14.

[22] Faria, D.A., Vilas Boas, A.A., Pires, A.A.S. and Morin, E.M. (2017) Fatores de Qualidade de Vida no Trabalho dos Docentes de Instituições Federais de Ensino Superior do Brasil. X Congresso de Administração, Sociedade e Inovação, Petrópolis, Vol. 1, 1-12.

[23] Faria, D.A., Vilas Boas, A.A. and Pires, A.A.S. (2017) Fatores de Qualidade de Vida no Trabalho dos Docentes de Instituições Federais de Ensino Superior do Estado de Minas Gerais. IV Congresso Lusófono em Comportamento Organizacional e Gestão, São Paulo, Vol. 1, 1-17.

[24] Thorndike, R.K. (1920) Inteligência e seus usos. Harper's Magazine, 140, 227-335.

[25] Gardner, H. (1983) Frames of Mind: The Theory of Multiple Intelligences. Basic Books, New York.

[26] Smith, M.K. (2002) Howard Gardner and Multiple Intelligences. The Encyclopedia of Informal Education.

[27] Payne, W.L. (1986) A Study of Emotion: Developing Emotional Intelligence; Self Integration; Relating to Fear, Pain and Desire. Dissertation Abstracts International, 47, 203A.

[28] Leuner, H. (1966) Emotional Intelligence and Emancipation. A Psychodynamic Study on Women. Prax Kinder Psychology, 15, 196-203.

[29] Salovey, P. and Mayer, J.D. (1990) Emotional Intelligence. Imagination, Cognition, and Personality, 9, 185-211. https://doi.org/10.2190/DUGG-P24E-52WK-6CDG

[30] Goleman, D. (1995) Emotional Intelligence. Bantam Books, New York.

[31] Petrides, K.V. and Furnham, A. (2000) On the Dimensional Structure of Emotional Intelligence. Personality and Individual Differences, 29, 313-320. https://doi.org/10.1016/S0191-8869(99)00195-6

[32] Mikolajczak, M.M., Luminet, O., Leroy, C. and Roy, E. (2007) Psychometric Properties of the Trait Emotional Intelligence Questionnaire: Factor Structure, Reliability, Construct, and Incremental Validity in a French-Speaking Population. Journal of Personality Assessment, 88, 338-353. https://doi.org/10.1080/00223890701333431

[33] Petrides, K.V. (2009) Technical Manual for the Trait Emotional Intelligence Questionnaires (TEIQue). London Psychometric Laboratory, London.

[34] Morin, E.M. (2008) The Meaning of Work, Mental Health and Organizational Commitment. Studies and Research Projects, Report R-585, HEC CA (Avec Collaboration of Francisco Aranha, FGV-EAESP), 65 p.

[35] Morin, E., Tonelli, M.J. and Pliopas, A.L.V. (2003) O trabalho e seus sentidos. Anais XXVII Encontro Anual da Associação Nacional de Pós graduação em Administração, Atibaia.

[36] Fernandes, E.C. (1996) Qualidade de Vida no Trabalho: Como medir para melhorar. Casa da Qualidade, Salvador.

[37] Silva, N. and Tolfo, S.R. (2012) Trabalho Significativo e Felicidade Humana: Explorando Aproximações. Revista Psicologia: Organizações e Trabalho, 12, 342.

[38] Morin, E.M. and Dassa, C. (2004) Characteristics of a Meaningful Work: Construction and Validation of a Scale. HEC Montréal/Université de Montréal, Montréal.

[39] Walton, R. (1973) Quality of Working Life: What Is It? Slow Management Review, $15,11-21$.

[40] Mendonça, C.H., Vilas Boas, A.A. and Morin, E.M. (2016) Qualidade de Vida no 
Trabalho de Professores da Rede Estadual de Educação de Minas Gerais. In: Encontro da Associação Nacional dos Programas de Pós-graduação em Administração, Costa do Sauípe BA. Anais do XL EnANPAD.

[41] Robbins, S.P. (2005) Comportamento Organizacional. 11th Edition, Pearson Prentice Hall, São Paulo.

[42] Meyer, J.P. and Allen, N.J. (1984) Testing the "Side-Bet Theory" of Organizational Commitment: Some Methodological Considerations. Journal of Applied Psychology, 69, 372-378. https://doi.org/10.1037/0021-9010.69.3.372

[43] Meyer, J.P. and Allen, N.J. (1991) A Three-Component Conceptualization of Organizational Commitment. Human Resource Management Review, 1, 61-89.

https://doi.org/10.1016/1053-4822(91)90011-Z

[44] Moorman, R.H. (1991) Relationship between Organizational Justice and Organizational Citizenship Behaviors: Do Fairness Perceptions Influence Employee Citizenship? Journal of Applied Psychology, 76, 845-855. https://doi.org/10.1037/0021-9010.76.6.845

[45] Gropher, D. and Donchin, E. (1986) Workload: An Examination of the Concept. In: Boff, K., Kaufman, L. and Thomas, J.P., Eds., Handbook of Perception and Human Performance, Wiley, New York, 41, 1-27.

[46] Matthews, G., Campbell, S.E., Falconer, S., Joyner, L.A., Huggins, J. and Gilliland, K. (2002) Fundamental Dimensions of Subjective State in Performance Settings: Task Engagement, Distress and Worry. Emotion, 2, 315-340. https://doi.org/10.1037/1528-3542.2.4.315

[47] Grech, M.R., Neal, A., Yeo, G., Humphreys, M. and Smith, S. (2009) An Examination of the Relationship between Workload and Fatigue within and across Consecutive Days of Work: Is the Relationship Static or Dynamic? Journal of Occupational Health Psychology, 14, 231-242. https://doi.org/10.1037/a0014952

[48] Limongi-França, A.C. (2004) Qualidade de vida no trabalho QVT: Conceitos e práticas nas empresas da sociedade, pós-industrial. 2nd Edition, Atlas, São Paulo.

[49] Zuin, A.A.S. and Bianchetti, L. (2015) O produtivismo na era do "publique, apareça ou pereça”: Um equilíbrio difícil e necessário. Caderno de Pesquisa, 45, 726-750. https://doi.org/10.1590/198053143294

[50] Wortman, C., Biernat, M. and Lang, E. (1991) Coping with Role Overload. In: Frankenhaeuser, M., Lundberg, U. and Chesney, M., Eds., Women Work and Health: Stress and Opportunities, Plenum, London, 85-110.

https://doi.org/10.1007/978-1-4615-3712-0_5

[51] Lori, F. and Barling, J. (2005) Organizational Injustice and Psychological Strain. Canadian Journal of Behavioral Science, 37, 250-261. https://doi.org/10.1037/h0087260

[52] Cheng, G.H.L. and Chan, D.K.S. (2008) Who Suffers More from Job Insecurity? A Meta-Analytic Review. Applied Psychology, 57, 272-303. https://doi.org/10.1111/j.1464-0597.2007.00312.x

[53] Sverke, M., Hellgren, J. and Näswall, K. (2002) No Security: A Meta-Analysis and Review of Job Insecurity and Its Consequences. Journal of Occupational Health Psychology, 7, 242-264. https://doi.org/10.1037/1076-8998.7.3.242

[54] Yin, R. (2005) Estudo de caso: Planejamento e métodos. 3rd Edition, Bookman, Porto Alegre.

[55] Gil, A.C. (2002) Como Elaborar Projetos de Pesquisa. 6th Edition, Atlas, São Paulo.

[56] Malhotra, N.K. (2006) Pesquisa de Marketing:uma orientação aplicada. Bookman, Porto Alegre.

[57] Hair Jr., J.F., Anderson, R.E., Tathan, R.L. and Black, W.C. (2005) Análise multivariada de dados. 5th Edition, Bookman, Porto Alegre.

[58] Dohrenwend, B.P. (1973) Some Issues in the Definition and Measurement of Psychiatric Disorders in General Populations. In: Proceedings of the 14th National 
Meeting of the Public Health Conference on Records and Statistics, DHEW Publication No. (HRA) 74-1214, National Center for Health Statistics, Washington DC, Government Printing Office, 480-489.

[59] Vidulich, M.A. and Tsang, P.S. (1986) Techniques of Subjective Workload Assessment: A Comparison of SWAT and the NASA-Bipolar Methods. Ergonomics, 29, 1385-1398. https://doi.org/10.1080/00140138608967253

[60] Vilas Boas, A.A. and Morin, E.M. (2013) Quality of Working Life in Public Higher Education Institutions: The Perception of Brazilian and Canadian Professors. International Journal of Business and Social Science, 4, 67-77.

[61] Vilas Boas, A.A. and Morin, E.M. (2014) La Qualité de Vie au Travail des professeurs des établissements publics d'enseignement supérieur: Une comparaison entre le Brésil et le Canada. Rapport de Recherche de post-doctorale, HEC, Montreal, $119 \mathrm{p}$. 